DOI: $10.17516 / 1997-1370-0670$

УДК 343.01

\title{
Counteraction to Corruption Offenses in Penitentiary System (in Memory of Doctor of Law, Professor Nikolay Shchedrin)
}

\author{
Natalia S. Maloletkina ${ }^{a}$, Andrey P. Skiba ${ }^{b}$ \\ and Alexey V. Rodionov*b \\ ${ }^{a}$ Samara Law Institute of the Federal Penitentiary Service of Russia \\ Samara, Russian Federation \\ ${ }^{b}$ Academy of the Federal Penitentiary Service of Russia \\ Ryazan, Russian Federation
}

Received 23.12.2019, received in revised form 31.08.2020, accepted 05.10.2020

\begin{abstract}
The subject of the research is the processes of combating corruption in the penitentiary system of Russia. The purpose of the research is to analyze the legal prerequisites for the emergence of corruption manifestations in the penitentiary system and search for promising areas of legislation improvement in this area. The work is based on the complex application of a number of general and special research methods (structural and functional analysis, comparative-legal, formal-logical, system-structural methods). Domestic and foreign regulations, official data of the Federal Penitentiary Service of Russia, the results of the Russian and foreign scholars' research serve the information base of the research. The main result of the research is in substantiation of the essential conclusions about the need for a clearer definition of the penitentiary system officials' powers in order to reduce the risks of committing acts with the signs of corruption. The most significant, regarding the risks of corruption manifestations, spheres of penitentiary system employees' activity are defined. The directions of law enforcement practice improvement in the sphere under the research are substantiated. The materials of the research can be useful for both scientists-penitentiaries, practitioners and for students, undergraduates and graduate students of the relevant areas of training and specialties in the course of mastering special disciplines.
\end{abstract}

Keywords: penitentiary system, corruption combating, correction of convicts, the regime of serving the sentence.

Research area: criminal law, criminology, penal law.

Citation: Maloletkina, N.S., Skiba, A.P., Rodionov, A.V. (2020). Counteraction to corruption offenses in penitentiary system (in memory of doctor of law, professor Nikolay Shchedrin). J. Sib. Fed. Univ. Humanit. Soc. Sci., 13(10), 1644-1651. DOI: 10.17516/1997-1370-0670.

\footnotetext{
(C) Siberian Federal University. All rights reserved

* Corresponding author E-mail address: avrpost@bk.ru ORCID: 0000-0002-9311-4896 (Rodionov)
} 


\section{Introduction}

Anti-corruption issues have long been in the focus of economic and legal science. They are particularly acute at the present stage, which is explained by the emergence of new forms of corruption offenses. This kind of situation is largely due to the inroads into new technical means and active digitalization in the financial sector, which significantly increases the possibility of implementing corruption actions by the offenders.

Intentional capture of improper benefits by the officials prevents the state bodies from normal activities. The level of trust of the population and the public to the state and to its certain divisions decreases. Corruption manifestations have a negative impact on the prestige of the state in the international arena, as well as on the processes of achieving social harmony within the country.

This problem is also relevant for the penitentiary system of Russia. This is largely due to the initially high level of requirements for compliance with anti-corruption legislation in the system of bodies and institutions executing the penalties for non-compliance. The penitentiary system is a state body, which, first of all, aims at achieving the goals of correction of convicts and prevention of new crimes, which, accordingly, increases its responsibility to the society.

The relevance of this research topic is largely determined by the specifics of anti-corruption activities in the penitentiary system. It is caused by shortcomings of penal and other legislation, features of illegal actions of the corresponding officials, methods and techniques for countering the implementation of anti-corruption measures in the penitentiary system, the specifics of committing corruption offenses.

\section{Problem statement}

The theory of intersectoral security measures aimed at neutralizing various threats, including corruption, plays an important role in the area under the research. It seems that security measures against a person who has committed a crime are not directly specified in Russian legislation and insufficiently researched inter-sectoral institution, including criminal and penal law. Currently, the security measures concept that was developed at the theoretical level by N. Shchedrin attracts many other researchers' attention. In the National Security Strategy of the Russian Federation until 2020, corruption and economic crimes are named among the main sources of internal threats to public development and the rule of law.

\section{Theoretical and empirical basis of the research}

The scientific and theoretical basis of this research grounds on scientific works of the specialists in the fields of economics, philosophy, theory of state and law (Torres, Garrido, 2014), criminal (Mazza, 2019), penal (Nikolaev, 2019) and administrative law (Cleff, Naderer, Volkert, 2011), criminology (Worley, Tewksbury, Frantzen, 2010), and other legal sciences (Worley, Tewksbury, Frantzen, 2010). The logic and content of the article are largely based on the experience of foreign scholars specializing in the implementation of anti-corruption legislation in the penitentiary sphere (Woodiwiss, 2015). The normative base of the research is the provisions of the Constitution of the Russian Federation, laws and bylaws of national legislation that regulate the relations in the field of combating corruption. The substantiation of the conclusions and proposals was based on the experience in the implementation of anti-corruption policy of the European German-speaking federal countries of the Romano-Germanic legal family, as well as economically developed countries of the Anglo-American legal family (USA, UK, and Canada).

The empirical basis of the research is the results of the author's research of the problems of combating corruption, including the penetration of prohibited items into the territory of correctional institutions. This research was conducted on the basis of correctional facilities in five regions (Samara, Ryazan, Rostov, Tver, and Saratov regions) in 2017-2018. The official data of the Federal Penitentiary Service of Russia concerning the practice of suppressing the illegal actions of a corruption nature, related to the employees of the Service, or those committed on the territory of subordinate institutions were also used. 


\section{Methodological basis}

The methodological basis of the work is a complex of general scientific and specific research methods. The comparative legal method was used for the analysis of the national anti-corruption legislation and the peculiarities of its application in the penitentiary sphere, taking into account the most progressive changes in the legislation of foreign countries. The structural and functional analysis was aimed at determining the compliance of the existing anti-corruption legislation with objectively existing features of the domestic penitentiary system functioning. The formal-logical method was applied to interpret basic concepts and categories, to substantiate intermediate conclusions and proposals. The systemic-structural research method was used in the analysis of the main components of corruption crimes.

\section{Discussion}

In Article 1 of the Federal law of December 25, 2008 No. 273-FZ "On combating corruption" the concept of corruption is presented in the form of abuse of official position, bribery, acceptance of bribe, abuse of power, commercial bribery or other illegal use by an individual of his/her official position contrary to the legitimate interests of the society and the state in order to obtain benefits in the form of money, valuables, other property-related services, other property rights for him/herself or for third parties or illegal provision of such benefits to the specified person by other individuals, as well as performing acts on behalf of or in the interests of a legal entity.

The researchers generally present corruption as reflection of a moral state of society, a set of official crimes (and other offenses) made by the officials (and other persons) against the state power, interests of public service and service in local self-government bodies, abuse of state power. Yet, at the same time they criticize the provisions of Federal law of December 25, 2008 No. 273-FZ "On combating corruption" (Bugaevskaya, 2016; Kabanov, 2015; Shchedrin, 2009).

By its nature, corruption is dangerous for the society due by increasing organized crime, slowing down the economic development, in- fringing on the citizens' constitutional rights and interests as well as undermining the foundations of state power, and threatening the rule of law.

A certain level of corruption crimes committed by the employees of the penitentiary system indicates the relevance of this problem and its practical significance. Since the Federal Penitentiary Service of Russia (hereinafter the FPS of Russia) is an executive body, then, accordingly, the employees of the bodies and institutions of the penitentiary system act on behalf of the state itself, thereby performing a large number of functions and duties to monitor and comply with the rule of law in their professional activities. Unfortunately, it is not always that the employees of the FPS of Russia comply with the law. In this case it is necessary to dwell upon the employee's personal qualities, his/her professional characteristics. Thus, psychologists should carry out more qualitative forecasting and prevention of corruption among constant and variable stuff.

Historically, any state at different stages of its development has gone through a period of surge or decrease in crimes and other corruption-related offenses. Correctional institutions are a place of concentration of persons, a significant part of whom systematically and professionally carried out criminal activities. Being in places of deprivation of liberty with appropriate measures of isolation from the society significantly reduces the potential for this social category's criminal activity, but does not ensure their complete rejection of the desire to continue their illegal activities even while serving imprisonment.

This can be analyzed on a number of examples. In the framework of administrative law, in accordance with Article 19.12 of the Code of Administrative Offences of the Russian Federation (hereinafter - CAO of the Russian Federation), transmission or attempted transmission of prohibited objects to persons detained in prisons is one of the typical offenses committed in correctional institutions. In accordance with the norms of the Penal code of the Russian Federation (hereinafter - the PC of the Russian Federation), convicts are prohibited from carrying prohibited items within the regime in correctional institutions. 


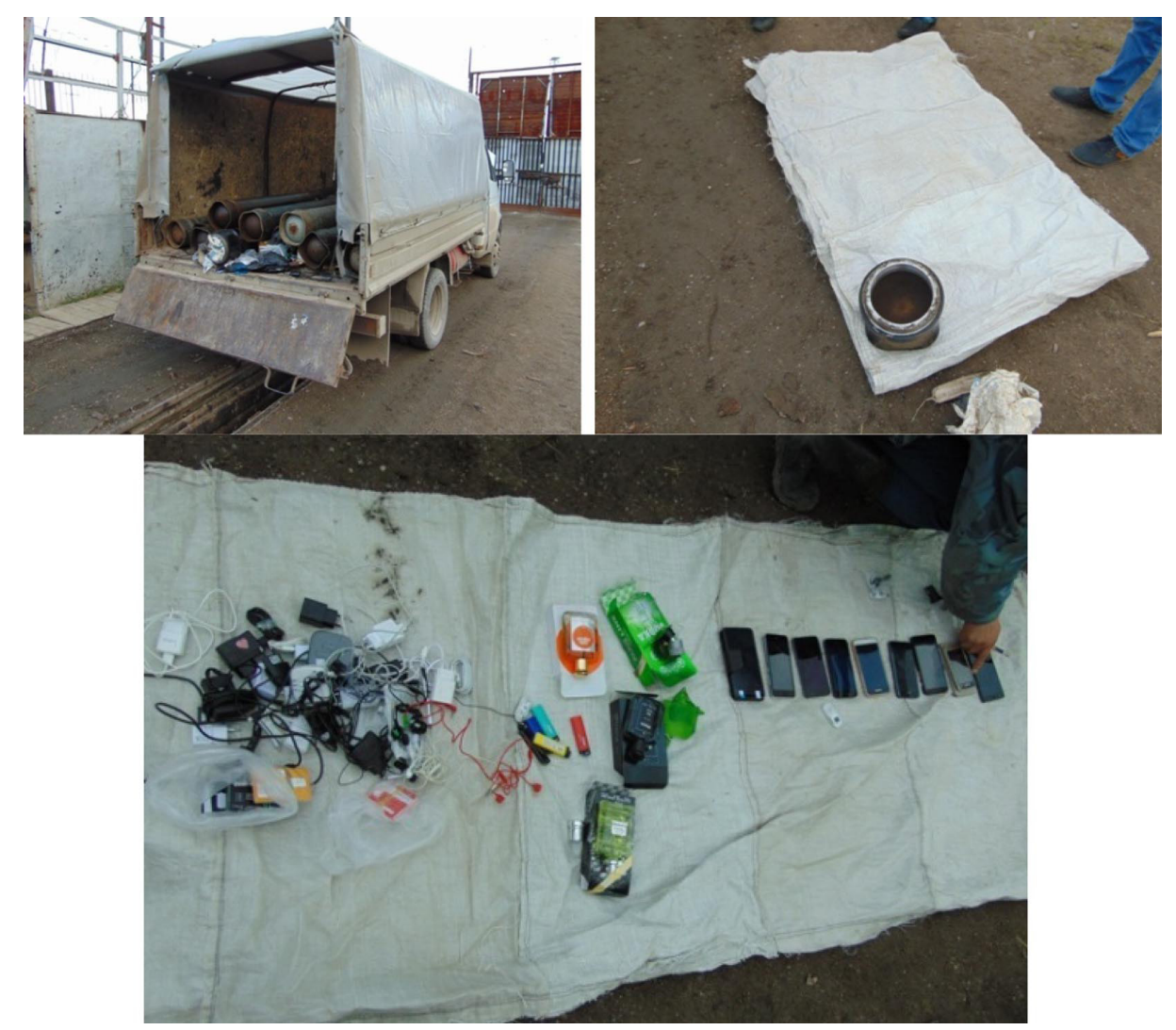

Fig. 1. The materials of criminal investigation by the Perm regional office of the FPS of Russia ${ }^{1}$

Prohibited items in places of deprivation of liberty are those items, means, devices, or substances, that cause or may cause a further threat to the life and health of convicts and employees of the penitentiary system, may serve as obstacles to the process of correcting the convicts, tools or methods of committing illegal acts, as well as threaten the safety of the institution as a whole. The list of items and foods that convicts are prohibited to have, to receive in parcels or purchase is specified in the Order of the Ministry of Justice of the Russian Federation dated 16.12.2016, № 295 “On Approval of the Internal Regulations in Correctional Institutions".

As per the results of our research, based on the example of the five regions, in the number of correctional institutions the ways of getting the prohibited items by the convicts are the following: throwing over the fence (most common response); carrying through a control checkpoint in disguise; concealment in parcels, letters; transportation in vehicles; hiding in the recesses, and also bribery of the staff in the protected object.

Offenders hide prohibited items in various places in the most sophisticated ways. For example, on September 17, 2019, the employees of the FPS of Russia in the Perm region stopped the attempts to deliver prohibited items to the territory of regime institutions. At the checkpoint of the institution, during the inspection of the car they found a double bottom in the oxygen cylinders intended for the production needs of the colony, the cylinders being the arsenal of prohibited means: 10 cell phones, 18 chargers, 12 headsets, 1 Bluetooth headset, 5 lighters, 72 SIM cards, and 4 bottles of eau de toilette (Fig. 1).

\footnotetext{
1 Krupnuiu partiiu zapreshchennykh predmetov pytalis' dostavit' na territoriiu IK-10 GUFSIN Rossii po permskomu kraiu [An attempt to deliver a large batch of prohibited items
} 
Sometimes the ones who are convicted to imprisonment keep the cell phones they illegally get. The suppression of such situations is largely related to the implementation of anti-corruption measures, as a number of cases of prohibited means of communication entering the territory of places of deprivation of liberty, bypassing regime requirements, can potentially be associated with the Commission of corruption crimes by the employees of the penitentiary system.

Corruption-related actions are usually detected by the employees of the relevant operational divisions of the FPS of Russia, who for a certain period of time often monitor and profile those who are prone to illegal actions and fall into their field of vision according to the convicts' and other persons' information. For the last two years Samara regional office of the FPS of Russia have arrested three employees in management positions and brought them to justice for the acts of corruption.

Article 9 of Federal law No. 273 of 25.12.2008 "On combating corruption" establishes a requirement that applies to all employees of the penitentiary system without exception. This requirement implies the obligation of the civil servants to promptly notify the head of appeals for the purpose of inducing to commit corruption offenses (which is stipulated in the departmental legislation). In case of concealment and failure to comply with this requirement, the employee may be dismissed or brought to other types of responsibility.

One of the main reasons for the dismissal of persons with high positions in the public service is violation of anti-corruption legislation. In the FPS of Russia, commissions on observance of requirements to office behavior and settlement of conflict of interests function on the basis of Order No. 693 of the FPS of Russia from 31.07.2015; Order No. 256 of the FPS of Russia from 29.05.2010 approves an accurate order of notifying about the facts of inciting to commit various corruption offenses; Order of the FPS of Russia No. 5 from

to the territory of Correctional facility $\# 10$ of the Central Department of the FPS of Russia in the Perm region]. Available at: https://www.59.fsin.su/news/detail.php?ELEMENT_ ID $=474682$ (accessed 15 June 2019).
11.01.2012 approves the code of office conduct and ethics of employees and civil servants of penitentiary service. There is also a set of other legal acts, according to which the employees provide the information regarding their property, income, property obligations and expenses. Since the introduction of mandatory declaration on the employee's income, the number of corruption actions has decreased, as this measure is quite effective in preventing corruption.

The existing norms regulating the disciplinary responsibility of the employees of the penitentiary system prove the importance of preventive anti-corruption impact of administrative and legal norms. CAO of the Russian Federation contains several articles of direct relevance to the activities of penitentiary system. For example, Article 7.29 refers to the failure to comply with the requirements of the legislation of the Russian Federation on contract system in procurement; Article 5.59 discloses the responsibility for violating the procedure of considering the citizens' applications; Article 19.32 specifies the issues of violation of the legislation on public control over human rights in places of forced detention; Article 19.29 provides for the state's or a municipal employee's liability for illegal employment or for performance of works or rendering of services. However, for example, the administrative code of the Russian Federation lacks the rule on responsibility for receiving a gift. The judicial practice recognizes it as a minor insignificant act of receiving the illegal remuneration by the official for making use of his official position against the interests of service. In this regard, we believe that it would be appropriate to introduce an article on administrative responsibility for corruption offenses, as well as for abuse and abuse of authority into the CAO of the Russian Federation.

It is also reasonable to consider the issue of unclear assignment of powers to the heads of correctional institutions, their power leaving much to their subjective discretion. This can lead to committing corruption crimes and other offenses. It is worth while considering some of them. According to Part 2 of Article 89 of the PC of the Russian Federation, the head of the 
correctional institution may take a decision on granting the extended visits to the convict, not only with close relatives but with other persons (without specifying them - the authors' notes); according to Part 6 of Article 97, the head of the institution may allow the convicted person to travel outside the correctional facility, "taking into account the nature and severity of the crime, the part of the served term, the convicted person's personality and behavior" (the legislative wording is used here - the authors' notes); Part 1 of Article 100 stipulates neither criteria nor forms of providing the imprisoned women an opportunity to living with children; parts 2 and 3 of Article 116 provide for two "alternatives" of possible recognition of the convicted person as a malicious violator of the established procedure for the served term (it is the former who is characterized by the subjective discretion of the head of the institution the authors' notes), etc.

There are other examples of such a vague regulation of the powers of the penitentiary system employees, for example, while implementing the Institute of parole. According to Part 2 of Article 175 of the PC of the Russian Federation, after filing of the petition of the convicted person on parole the administration of the correctional institution directs to court the specified petition together with the characteristic on the prisoner, the characteristic containing the data on the convicted person's behavior, his/her attitude to education and work, the convict's attitude to committing the act on compensation for crime damage, and the conclusion of the administration on the advisability of parole. However, there are no clear recommendations on this matter in the law. As a result, the final conclusion may differ, the data being similar: for example, for several incentives and one penalty or, identically, for several repaid or withdrawn penalties and one incentive, etc. the convict can be characterized either positively or negatively. Consequently, a corruption-related situation has been created by law: depending on the subjective discretion, the relevant officer of the criminal investigation department can formulate radically different conclusions, which is hardly acceptable. It seems that the provisions of the penal enforcement and other legislation (having conflicts, "white spots", and other numerous shortcomings) should clearly define the powers of the relevant officials of the institutions and bodies executing sentences in order to exclude subjectivity in their application.

\section{Conclusion}

Regarding the corruption in the society as a whole and in the penitentiary system, in particular, it is necessary to simultaneously consider the issues of combating crimes and other corruption-related offenses. It seems that appropriate prevention should be carried out at a minor age at school already to disclose the negative aspects and consequences of corruption, its content, types of corruption, causes and conditions of corruption offenses, as well as to give specific examples of violations of anti-corruption and other legislation. Systematic work with young people in this area will allow future students and cadets of higher educational institutions to have primary knowledge on combating corruption (Shchedrin, 2018). Special attention should be paid to anti-corruption education of the entire personnel of the penitentiary system (N. Shchedrin, in particular, dwelt upon the importance of this area of anti-corruption prevention), including through preventive interviews with certain employees who, according to operational information, have criminal intentions and must perform duties in accordance with Article 9 of Federal law of December 25, 2008 No. 273-FZ "On combating corruption". Thus, it seems that the improvement of the penal, administrative and other legislation will increase the effectiveness of combating corruption in the penitentiary system.

\section{References}

Bugaevskaya, N.V. (2016). K voprosu ob opredelenii bazovykh poniatii v sfere protivodeistviia korruptsii [On the definition of the basic concepts of anti-corruption]. In Izvestiia Tul'skogo gosudarstvennogo 
universiteta. Ekonomicheskie i iuridicheskie nauki [Izvestiya Tula State University. Economic and Legal Sciences], 4-2, 77-82.

Cleff, T., Naderer, G., Volkert, J. (2011). Motive der Wirtschaftskriminalität: Ergebnisse einer quantitativen und qualitativen Studie. Monatsschrift fur Kriminologie und Strafrechtsreform, 94 (1), 4-16.

Kabanov, P.A. (2015). Poniatie i soderzhanie antikorruptsionnogo prosveshcheniia kak sredstva profilaktiki korruptsii [The concept and content of anti-corruption education as a means of preventing corruption]. In Iuridicheskie issledovaniia [Legal Studies], 2, 12-27.

Mazza, O. (2019). Immediate imprisonment of corrupt: A misconstruction of intertemporal law in legislator's complicit silence [La carcerazione immediata dei corrotti: una for-zatura di diritto intertemporale nel silenzio complice del legislatore]. In Archivio Penale, 71 (2).

Nikolaev, S.M. (2019). Modeling of cadets' preparation in educational establishments of higher education of the penitentiary system for anti-corruption activities. In Espacios, 40 (29).

Petrov, A.A. (2017). Strategii preodoleniia kollizii v prave: poniatie, vidy, effektivnost' [On strategies of overcoming collisions in law: concept, taxonomy, efficiency]. In Iuridicheskaia tekhnika: ezhegodnik [Legal technique: the annual], 11, 262-264.

Shchedrin, N.V. (2009). Opredelenie korruptsii v federal'nom zakone [Definition of corruption in the Federal law]. In Kriminologicheskii zhurnal Baikal'skogo gosudarstvennogo universiteta ekonomiki i prava [Criminological Journal of Baikal National University of Economics and Law], 3, 31-36.

Shchedrin, N.V. (2018). Problemy antikorruptsionnogo prosveshcheniia [Problems of anti-corruption education: Proceedings of the Second Siberian Anti-corruption Forum "Current problems of anti-corruption awareness and anti-corruption education"]. Krasnoiarsk, Siberian Federal University, 112-119.

Torres, M.A.R., Garrido, E.A. (2014). Cuadrar el delito. Corrupción institucional y participación de policías en el secuestro en México. In Perfiles Latinoamericanos, 23 (44), 91-112.

Woodiwiss, M. (2015). The analysis and containment of organized crime in New York City and beyond: an interview with James B. Jacobs. Trends in Organized Crime, 18 (1-2), 86-93.

Worley, R.M., Tewksbury, R., Frantzen, D. (2010). Preventing fatal attractions: Lessons learned from inmate boundary violators in a southern penitentiary system. In Criminal Justice Studies, 23 (4), 347-360. 


\title{
Противодействие коррупционным правонарушениям в уголовно-исполнительной системе (памяти доктора юридических наук, профессора Николая Васильевича Щедрина)
}

\author{
Н.С. Малолеткина , А.П. Скибаб, А.В. Родионовб \\ ${ }^{a}$ Самарский юридический институт \\ Федеральной службы исполнения наказаний России \\ Российская Федерачия, Самара \\ ${ }^{6}$ Академия права и управления \\ Федеральной службы исполнения наказаний России \\ Российская Федерация, Рязань
}

\begin{abstract}
Аннотация. Предметом исследования являются процессы противодействия коррупции в уголовно-исполнительной системе России. Цель исследования состоит в анализе правовых предпосылок возникновения коррупционных проявлений в уголовно-исполнительной системе и поиске перспективных направлений совершенствования законодательства в данной сфере. Работа построена на комплексном применении ряда общих и специальных методов исследования (структурнофункциональный анализ, сравнительно-правовой, формально-логический, системно-структурный методы). Информационная база исследования представлена отечественными и зарубежными нормативными актами, официальными данными Федеральной службы исполнения наказаний России, результатами исследований российских и зарубежных авторов. Основной результат исследования состоит в обосновании выводов о необходимости более четкого определения полномочий должностных лиц уголовно-исполнительной системы с целью снижения рисков совершения действий, имеющих субъективный характер и, возможно, способствующих коррупционным проявлениям. Определены наиболее существенные с точки зрения рисков возникновения коррупционных проявлений сферы деятельности сотрудников уголовно-исполнительной системы. Обоснованы направления совершенствования правоприменительной практики в исследуемой сфере. Материалы исследования могут быть полезными для ученых-пенитенциаристов, практиков, а также в ходе изучения специальных дисциплин студентам, магистрантам и аспирантам соответствующих направлений подготовки и специальностей.
\end{abstract}

Ключевые слова: уголовно-исполнительная система, противодействие коррупции, исправление осужденных, режим отбывания наказаний.

Научная специальность: 12.00 .08 - уголовное право, криминология, уголовноисполнительное право. 